\title{
Rich Dad, Smart Dad: Decomposing the Intergenerational Transmission of Income*
}

\author{
Lars Lefgren \\ Brigham Young University \\ Matthew J. Lindquist \\ Stockholm University \\ David Sims \\ Brigham Young University
}

December 10, 2009

\begin{abstract}
We construct a simple model, consistent with Becker and Tomes (1979), that decomposes the intergenerational income elasticity into the causal effect of financial resources, the mechanistic transmission of human capital, and the role that human capital plays in the determination of father's permanent income. We show how a particular set of instrumental variables could separately identify the money and human capital transmission effects. We further outline two instrumental variables methods for bounding the structural parameters of our model in the presence of imperfect instruments. Using data from a thirty-five percent sample of Swedish sons and their fathers, we show that only a minority of the intergenerational income elasticity can be plausibly attributed to the causal effect of fathers' financial resources.
\end{abstract}

Keywords: financial resources, human capital, intergenerational income elasticity, intergenerational mobility, permanent income.

JEL code: J62

\footnotetext{
${ }^{*}$ We would like to thank Anders Björklund and seminar participants at Brigham Young University, the Federal Reserve Bank of Chicago, Michigan State University, Princeton University, Stockholm University and the University of Arizona. The data used in this paper were financed by the Swedish Council for Work Life and Social Research (FAS).
} 


\section{Introduction}

The literature reviews of Björklund and Jäntti (2009) and Solon (1999) provide numerous examples of empirical studies that have carefully measured the intergenerational income elasticity (IIE) for a variety of countries. This literature has provided us with valuable information concerning the role of family background in determining economic success. However, this research agenda has to date produced less than a handful of empirical studies that provide insight into the structural mechanisms that underlie this transmission of income from father to son. Thus, it remains unclear whether an IIE estimate should be interpreted as the causal effect of financial resources on child quality, the mechanistic persistence of genetic or human capital differences, or something else entirely. ${ }^{1}$ In this paper, we develop an approach to identify the mechanisms through which the IIE operates. We show how this approach can be used to discern the relative importance of paternal income versus human capital (broadly defined) in intergenerational income mobility.

We begin with a simple model (consistent with Becker and Tomes 1979) in which paternal human capital and financial investments have separate effects on child quality as measured by income. In this setting ordinary least squares (OLS) estimates of the IIE converge to a weighted combination of these two effects. The weight on each factor depends on the relative importance of luck and human capital in determining paternal income. We further show how instrumental variables (IV) estimates of the IIE identify different combinations of the paternal human capital and financial resource effects with weights that depend on a particular instrument's covariance with paternal human capital and income due to luck.

\footnotetext{
${ }^{1}$ By mechanistic we mean the transmission of human capital that occurs as a consequence of being a father's son, independent of the level of financial investment. This mechanism includes genetic transmission of attributes, the power of example, and at-home non-financial investments.
} 
This insight allows us to test the assumption that the IIE operates through multiple mechanisms by comparing IV and OLS estimates. More specifically, under the null hypothesis that the IIE operates through a single mechanism, OLS and IV estimates (or any two IV estimates obtained from different correlates of paternal income) should be statistically indistinguishable. Thus rejecting this null hypothesis requires the IIE to operate through at least two mechanisms. Furthermore, given an instrument which is correlated only to the luck component of paternal income and another instrument which is correlated only to the human capital component, we can identify the structural parameters underlying the IIE in our model. Even if such instruments prove unobtainable, we show that IV estimation allows us to identify upper bound estimates of the role of financial resources and lower bound estimates of the importance of human capital using instrument sets derived from correlates for father's income that satisfy a simple monotonicity condition.

We further demonstrate how to bound the structural parameters in the absence of an instrument that effectively isolates variation in paternal income due to luck. More specifically, identification is achieved with an instrument that isolates variation in paternal income due to human capital combined with an estimate of the fraction of the variance in paternal income attributable to human capital. The r-squared from a simple Mincerian regression of paternal permanent income on measures of human capital provides a lower bound of this latter quantity. This in turn provides an alternative method to identify a lower bound of the mechanistic impact of human capital and an upper bound of the causal effect of paternal income.

Using a large dataset of Swedish fathers and sons that provides excellent data on permanent incomes, we estimate an IIE of 0.29 , consistent with prior estimates in the literature of Scandavian countries. When paternal permanent income is instrumented with education or 
related factors designed to capture the influence of human capital the estimated IIE is much higher, exceeding 0.40. This allows us to reject the one factor model. Though it is more difficult to find an instrument that captures a paternal income variation due to luck we present some candidates which provide significantly lower IIE estimates as predicted by our model. These results imply that approximately one-third of the intergenerational income transmission is due to variations in monetary income. Our alternative identification strategy, which relies on an estimate of a Mincer r-squared, yields looser bounds and therefore cannot rule out a somewhat larger role for the direct effect of financial resources. We show that these estimates are robust to alternative specifications and weighting schemes.

This paper proceeds with a description of how our study fits into the literature on intergenerational income inequality, the transfer of human capital, and the importance of parental financial resources. We then outline a simple model for the intergenerational transmission of income, which leads directly to our empirical strategy for identifying the structural parameters of the IIE. We follow by describing our data and then present our estimation results. We discuss threats to identification and present various robustness checks. We then conclude.

\section{Literature Review}

Björklund and Jäntti (forthcoming) and Solon (1999) review a large number of articles that attempt to measure the cross-generational correlation of income. Since these reviews provide an excellent summary of a large body of work, we will mention here only a few key findings that motivate our present study. In particular, these studies suggest that IIE estimates are quite sensitive to poor measures of permanent income. For example, Mazumder (2005) reports IIE estimates as high as 0.613 for the United States when sixteen years of earnings are used to 
construct measures of father's permanent income. This number falls to 0.472 when only six years of earnings are averaged. ${ }^{2}$

The second consistent finding is that IIE values of developed countries tend to fall into two classes. The U.S. estimates calculated by Mazumander (2005) are similar in magnitude to others obtained with American data such as Solon (1992) and Zimmerman (1992), as well as those from Italy (Piriano, 2007) and France (LeFranc and Trannoy, 2005). Other developed countries, however, tend to show much lower persistence in earnings. Indeed, estimates in Nordic countries tend to be much smaller, clustering close to 0.2 (see Björklund and Chadwick, 2003; Aakvik et al., 2006; Pekkarinen et al., 2009; and Hussain et al., 2008).

Given the increased understanding of descriptive facts about intergenerational income transmission that continues to come from this literature, a complementary investigation would naturally seek to determine the causal mechanisms through which this propagation occurs. Such mechanisms arise in the explicit economic models of intergenerational income correlation constructed by Becker and Tomes (1979), Becker and Tomes (1986), Checchi et al. (1999), Solon (2004), Davies et al. (2005), and Hassler et al. (2007). ${ }^{3}$ Unfortunately, for reasons discussed by Goldberger (1989), Grawe (2004), and Mulligan (1999) these models have proved difficult to test in a convincing fashion. In response to these difficulties, several recent studies have opted for a quasi-experimental approach for testing single mechanisms in isolation. For example, Pekkarinen et al. (2009) provide evidence that the Finnish comprehensive school reform of 1972-1977 lowered the IIE by 23 percent.

\footnotetext{
${ }^{2}$ The difference arises from the fact that each period's earnings is only a noisy measure of permanent income. Thus as one averages over a larger number of periods, the average of earnings becomes a more precise indicator of permanent income.

${ }^{3}$ For example, in Solon's (2004) version of the Becker and Tomes (1979) model, the IIE is a function of 4 factors: (1) the heritability of income-related traits, (2) the efficacy of human capital investment, (3) the earnings return to human capital, and (4) the progressivity of public investment in human capital. Structural models such as this one can help us to think more clearly about differences in the IIE across countries and across time.
} 
While we are not aware of any studies to date that have attempted a systematic structural decomposition of the role of human capital versus monetary resources, there is a separate literature that examines the intergenerational transmission of parental characteristics that might in part explain the transmission of income. ${ }^{4}$ For example, Bouchard and Matthew (1981), Black, Devereux, and Salvanes (2008) and Björklund, Hederos-Eriksson, and Jäntti (2009) describe the intergenerational transmission of IQ scores. Behrman and Rosenzweig (2002), Black, Devereux, and Salvanes (2005), Oreopoulos, Page, and Stevens (2006) and Holmlund, Lindahl and Plug (2008) examine the parental transmission of education. Hauser and Logan (1992) discuss the transmission of occupational status.

Similarly, a number of researchers have attempted to identify the causal effect of parental income on a variety of child outcomes, including earnings. Excellent examples include Dahl and Lochner (2005), Shea (2000), Mayer (1997), Blau (1999), and Carneiro and Heckman (2002). While these studies present a mixed picture regarding the role of financial resources on child quality, collectively they suggest that the raw correlation between parental income and child outcomes should not be interpreted causally. However, Mazumder (2005) and Corcoran et al. (1992) find that paternal education has no independent correlation with son's earnings once one controls for an accurate measure of father's permanent income. In the context of our model, this finding can be interpreted as accepting a single factor model of intergenerational income transmission. Their results are also consistent with the relationship between paternal and filial income reflecting primarily the causal effect of financial resources.

\footnotetext{
${ }^{4}$ The term "decomposition" has been used by previous authors in this literature (e.g., Blanden et al., 2007). Their decomposition experiments, however, are not intended to be interpreted in a causal sense. In contrast to this, we use the term "structural decomposition" to describe an exercise that examines the relative importance of different causal mechanisms underlying the IIE.
} 
Several studies within this strand of literature examine the impact of parents' income on children's outcomes when they are quite young, such as scholastic achievement tests and measures of behavioral development. Blau (1999) argues that these types of child outcomes do not correlate strongly with adult outcomes. Furthermore, such income induced gains may also be short-lived (Dahl and Lochner 2005). In contrast, our paper examines the impact of fathers' permanent income on sons' permanent income, an outcome of greater eventual importance. We can also measure permanent income quite accurately using Swedish income tax data. Other papers that look at earnings or family income of adult sons use much noisier measures of income, making it more difficult to draw strong inference.

The broader idea of running a structural decomposition exercise is not unique to our study. Several researchers have used adoption data in order to gauge the relative importance of nature and nurture. The most notable of these studies is Björklund, Lindahl and Plug (2006). They use Swedish adoption data to decompose the IIE into pre- and post-birth factors. Pre-birth factors include parents' genes and pre-natal environment. Post-birth factors include everything else. They find that both factors play a significant role in producing the observed IIE. ${ }^{5}$

Our examination of intergenerational income transmission mechanisms helps to connect these disparate literatures. Our approach is quite general and can be readily modified to include (for example) the type of nature-nurture decomposition presented in adoption IIE studies. ${ }^{6} \mathrm{We}$ posit an economic model consistent with Becker and Tomes (1979) in which financial resources may have a causal effect on child outcomes. We allow paternal characteristics such as education

\footnotetext{
5 Björklund, Jäntti and Solon (2007) extend this structural approach by allowing for differences in family composition. In related work, Björklund, Jäntti and Solon (2005) identify a structural model of nature and nurture which is used to explain sibling correlations in earnings by making using of varying degrees of genetic connections and shared rearing environments. They use full siblings, half siblings, adopted siblings, monozygotic and dyzygotic twins - all of whom may be raised either together or apart for varying amounts of time. For a recent review of the adoption - IIE literature see Liu and Zeng (2009).

${ }^{6}$ While our general approach can be readily modified to include the type of nature-nurture decomposition posited in adoption IIE studies, the reverse is not true.
} 
to have an independent effect on child quality. Relying on this simple structural model and a very rich dataset of father-son pairs from Sweden, we provide estimates of both the causal impact of financial resources and the direct rate of transmission of paternal human capital.

\section{Model}

When researchers measure the intergenerational transmission of income, they commonly estimate an equation of the following form:

$$
\text { inc } c_{\text {son }}=\beta_{0}+\beta_{1} i n c_{f a t h e r}+\varepsilon_{\text {son }}
$$

where $i n c_{\text {son }}$ and $i n c_{\text {father }}$ are the natural logarithm of income for the son and father respectively and $\varepsilon_{\text {son }}$ is a residual. ${ }^{7}$ Although empirical researchers typically make no claims regarding the causality of this relationship, it is useful to consider what structural parameters it actually captures. To see this, consider a slightly more complex model.

Suppose fathers differ in terms of human capital and income. Paternal income is a function of a father's human capital and other idiosyncratic factors. We write this relationship as:

$$
\text { inc }_{\text {father }}=\gamma+H C_{\text {father }}+\eta_{\text {father }} \text {. }
$$

In the current context, human capital, $H C_{\text {father }}$, consists of education, health, and genetic endowments that carry a return in the marketplace and is denominated in dollar equivalents, while $\eta_{\text {father }}$ captures variation in paternal income that is due to luck. This might include an

\footnotetext{
7 Solon (2004) modifies the Becker and Tomes (1979) model in a way that rationalizes the log-linear
} intergenerational income regression commonly estimated by empirical researchers. 
unusually good job match, benefiting from a generous union contract, etc. We assume that $\eta_{\text {father }}$ is orthogonal to paternal human capital. ${ }^{8}$

Fathers are interested in producing high quality sons as measured by income. This manifests itself in the following relationship:

$$
\text { inc } c_{\text {son }}=\pi_{0}+\pi_{1} i n c_{\text {father }}+\pi_{2} H C_{\text {father }}+v_{\text {son }} \cdot{ }^{9}
$$

This equation is identical to that derived in Becker and Tomes (1979) when one abstracts from the impact of average societal human capital. ${ }^{10}$ Thus each of the parameters can be given a structural interpretation. More specifically, $\pi_{1}$ corresponds to the fraction of income invested in child quality multiplied by the efficacy of this investment. ${ }^{11}$ Meanwhile $\pi_{2}$ captures the degree to which human capital is directly transferable to children, while allowing such transfers to be offset by reductions in financial investment. Even if the strong functional form assumptions of the Becker and Tomes (1979) model do not hold, equation (3) can be viewed as a linear approximation of a more complex behavioral/production model. ${ }^{12}$

Given, this assumed data generating process, it seems reasonable to simply estimate equation (3) by regressing sons' income on fathers' permanent income and proxies for father's human capital. Regressions by Mazumder (2005) and Corcoran et al. (1992), in which sons' income is regressed on fathers' permanent income and education, can be interpreted as attempts

\footnotetext{
${ }^{8}$ Given our broad view of human capital, it's not clear this independence assumption is restrictive. In particular, if an individual possesses a characteristic that would systematically raise wages in many counterfactual lives, it is encompassed in human capital. Thus luck, by construction, is that which is idiosyncratic to an individual's realized life outcome.

${ }^{9}$ If we denote son's human capital as $\pi_{1} i n c_{\text {father }}+\pi_{2} H C_{\text {father }}$, the data generating process for son's income is identical to the father's.

${ }^{10}$ It is also consistent with the data generating process in Shea (2000).

${ }^{11}$ In Becker and Tomes (1979) the fraction of income spent on investment in children is pegged by preference parameters of a Cobb-Douglas utility function. The efficacy of investments in equilibrium is determined by the market rate of interest.

${ }^{12}$ Mulligan (1999) and Goldberger (1989) point out the difficulties of determining whether the intergenerational correlation in income reflects optimizing behavior or a mechanistic convergence to the mean posited by Galton in the nineteenth century.
} 
in this direction. Unfortunately, because education and other available measures of human capital capture only a minority of the variation in human capital, one cannot effectively isolate the structural parameters of the model. Additionally, the probability limits of the resulting reduced form regression coefficients are very difficult to interpret. Finally, even if sufficiently good proxies for human capital are available to identify $\pi_{1}$, it would be unclear how the coefficients on the various human capital measures relate to $\pi_{2}$.

Moving forward with our preferred approach, we substitute equation (2) into equation (3) to obtain the following expression:

$$
\text { inc } c_{\text {son }}=\pi_{0}+\pi_{1} \gamma+\left(\pi_{1}+\pi_{2}\right) H C_{\text {father }}+\pi_{1} \eta_{\text {father }}+\nu_{\text {son }} .
$$

This equation captures the intuition that paternal human capital can affect child quality through an increase in financial investment as measured by $\pi_{1}$ and directly through $\pi_{2}$. The component of a father's income that is generated by luck affects his son's income only through increased financial investment.

Given this model, the OLS slope estimator for equation (1), $\hat{\beta}_{1}^{\text {oLS }}$ converges to:

$$
\operatorname{plim}\left(\hat{\beta}_{1}^{\text {oLS }}\right)=\pi_{1}+\pi_{2} \frac{\operatorname{var}\left(H C_{\text {father }}\right)}{\operatorname{var}\left(H C_{\text {father }}\right)+\operatorname{var}\left(\eta_{\text {father }}\right)} .
$$

Note that the first term captures the impact of paternal income, holding constant human capital. The second term captures the impact of paternal human capital on son's income. The term $\frac{\operatorname{var}\left(H C_{\text {father }}\right)}{\operatorname{var}\left(H C_{\text {father }}\right)+\operatorname{var}\left(\eta_{\text {father }}\right)}$ is the fraction of variance in father's income attributable to human capital variation. The key insight is that if variation in paternal income is due primarily to luck, then $\hat{\beta}_{1}^{\text {oLS }}$ reflects primarily financial investments in child quality. On the other hand, if 
variation in paternal income is primarily due to differences in human capital, $\hat{\beta}_{1}^{\text {oLS }}$, will also reflect the direct impact of father's human capital on child quality. Thus the structural interpretation of any particular OLS estimate depends crucially on the source of income variation for fathers in that particular study.

Because different sources of paternal income variation have different implications for filial income, alternative estimation methods have the potential to shed more light on the mechanisms underlying the intergenerational transmission of income. In particular, suppose there exists a correlate of paternal income, $Z_{\text {father }}$. Using this variable as an instrument for paternal income to identify the intergenerational correlation of income relationship of equation (1) yields the following probability limit:

$$
\operatorname{plim}\left(\hat{\beta}_{1}^{I V}\right)=\pi_{1}+\pi_{2} \frac{\operatorname{cov}\left(H C_{\text {father }}, Z_{\text {father }}\right)}{\operatorname{cov}\left(H C_{\text {father }}, Z_{\text {father }}\right)+\operatorname{cov}\left(\eta_{\text {father }}, Z_{\text {father }}\right)} .
$$

Like the OLS estimate, $\hat{\beta}_{1}^{I V}$ reflects the impact of paternal income operating through financial investments, $\pi_{1}$. The second term of the IV estimator takes into account the direct effect of paternal human capital on child quality. The expression $\frac{\operatorname{cov}\left(H C_{\text {father }}, Z_{\text {father }}\right)}{\operatorname{cov}\left(H C_{\text {father }}, Z_{\text {father }}\right)+\operatorname{cov}\left(\eta_{\text {father }}, Z_{\text {father }}\right)}$ represents the proportion of the covariance between income and the instrument that is attributable to human capital. It follows that each potential instrument is associated with a local average treatment effect (LATE) depending on its 
covariance with luck and human capital. ${ }^{13}$ That is, each instrument identifies a potentially different weighted combination of the structural parameters. ${ }^{14,15}$

This suggests that the properties of multiple estimation attempts can be leveraged to reveal information about the structural parameters of our model. For example, since $p \lim \left(\hat{\beta}_{1}^{I V}\right)=p \lim \left(\hat{\beta}_{1}^{\text {oLS }}\right) \quad$ if $\quad$ and $\quad$ only $\quad$ if $\quad \pi_{2}=0 \quad$ or $\frac{\operatorname{cov}\left(H C_{\text {father }}, Z_{\text {father }}\right)}{\operatorname{cov}\left(H C_{\text {father }}, Z_{\text {father }}\right)+\operatorname{cov}\left(\eta_{\text {father }}, Z_{\text {father }}\right)}=\frac{\operatorname{var}\left(H C_{\text {father }}\right)}{\operatorname{var}\left(H C_{\text {father }}\right)+\operatorname{var}\left(\eta_{\text {father }}\right)}$ (which will in general not hold if both $Z_{\text {father }}$ and $\eta_{\text {father }}$ have non-degenerate distributions), a significant difference between OLS and IV estimates implies that $\pi_{2} \neq 0$. Thus, a simple Hausman test can show that the transmission of income comes partially through a genetic or environmentally mediated direct parental human capital effect, rather than exclusively through the investment of additional financial resources. ${ }^{16}$ By the same token, unless $\pi_{2}=0$, any two instruments should yield a different value for the intergenerational income elasticity as long as they differ in their relative covariance with luck and human capital. Thus, rejecting a test of overidentifying restrictions in an IV context allows us to conclude that financial investments are not the sole mechanism through which income is transmitted from generation to generation. ${ }^{17}$

Furthermore, our model implies that a combination of suitable instruments could be used to disentangle the magnitudes of direct human capital and resource investment effects. Suppose

\footnotetext{
${ }^{13}$ See Imbens and Angrist (1994).

${ }^{14}$ Solon (1992) documents the difference between OLS and IV estimates of the intergenerational income elasticity. He views the IV estimate as upwardly biased. We would argue that bias can only be determined in the context of the structural parameters one is trying to estimate.

15 This intuition and the general empirical approach are similar to those used by Jacob, Lefgren, and Sims (forthcoming) to examine the persistence of teacher-induced learning gains.

${ }^{16}$ Even in a more general setting, a comparison of OLS and IV estimates tells whether there is a single mechanism through which paternal income correlates with son's income or multiple mechanisms. If a Hausman test is rejected, one can infer that multiple mechanisms are at work.

${ }^{17}$ An instrumental variables approach also has the advantage that it is robust to imperfect measures of permanent income as long as the instruments themselves are orthogonal to transitory fluctuations.
} 
that there exists an instrument that is related only to the luck component of paternal income. In this case, $\hat{\beta}_{1}^{I V}$ converges to $\pi_{1}$, the pure impact of a father's financial resources. Shea (2000) and Dahl and Lochner (2008) use such a strategy in attempts to identify the causal impact of financial resources on child outcomes. Alternatively, an instrument that is correlated only to paternal human capital and not luck will yield an estimate that converges to $\pi_{1}+\pi_{2}$, the impact of financial resources plus the impact of paternal human capital (where human capital is denominated in dollars). Thus, direct comparison of the two estimates allows separate identification of the two structural mechanisms.

Even in the absence of two such ideal instruments, this methodology allows us to establish bounds on the structural effects. Consider any instrument that satisfies the monotonicity condition that $\operatorname{cov}\left(H C_{\text {father }}, Z_{\text {father }}\right)$ and $\operatorname{cov}\left(\eta_{\text {father }}, Z_{\text {father }}\right)$ have the same sign. If this condition holds, the probability limit of the resulting IV estimate will necessarily lie between $\pi_{1}$ and $\pi_{1}+\pi_{2}$. Thus, abstracting from estimation error and assuming $\pi_{2} \geq 0$, the minimum estimate from using an arbitrary set of instruments yields an upper bound for $\pi_{1}$. While the maximum estimate yields a lower bound for $\pi_{1}+\pi_{2}$. Subtracting the minimum estimate from the maximum estimate yields a lower bound of $\pi_{2}$. If instruments are available such that $\pi_{1}$ and $\pi_{2}$ are identified or at least closely bounded, one can back out the fraction of variance in paternal income due to human capital from $\hat{\beta}_{1}^{\text {oLS }}$.

In practice, due to finite data, each IV estimate reflects both the probability limit and estimation error. As a result, the probability limit of the largest IV estimate will be on average smaller than the estimated coefficient with the opposite holding true for the smallest IV estimate. Bounding on the basis of the highest and lowest measured IV estimates is thus likely to lead to 
misleading bounds. One can address this by identifying ex-ante "luck" instruments, which are likely to have a relatively stronger relationship with $\eta_{\text {father }}$ than $H C_{\text {father }}$ and "human capital" instruments that behave in the opposite manner. One then simply uses the "luck" instrument to identify the upper bound of $\pi_{1}$ and the "human capital" instrument to identify the lower bound of $\pi_{1}+\pi_{2}$. The monotonicity condition must still hold.

A second bounding procedure is possible using only measures of human capital. More specifically, suppose we have a set of instruments, $Z_{\text {father }}^{h c}$, which are correlated to paternal human capital but uncorrelated to luck. Under this assumption, instrumental variables estimation of equation (1), $\hat{\beta}_{1}^{I V}$, identifies $\pi_{1}+\pi_{2}$. The corresponding OLS estimate, $\hat{\beta}_{1}^{\text {oLS }}$, converges to $\pi_{1}+\pi_{2} \frac{\operatorname{var}\left(H C_{\text {father }}\right)}{\operatorname{var}\left(H C_{\text {father }}\right)+\operatorname{var}\left(\eta_{\text {father }}\right)}$. With an estimate of $\frac{\operatorname{var}\left(H C_{\text {father }}\right)}{\operatorname{var}\left(H C_{\text {father }}\right)+\operatorname{var}\left(\eta_{\text {father }}\right)}$, one can recover $\pi_{1}$ and $\pi_{2}$. Since by assumption $Z_{\text {father }}^{\text {hc }}$ only affects paternal income through human capital, the r-squared of the Mincerian regression of paternal earnings on $Z_{\text {father }}^{\text {hc }}$ yields a lower bound of $\frac{\operatorname{var}\left(H C_{\text {father }}\right)}{\operatorname{var}\left(H C_{\text {father }}\right)+\operatorname{var}\left(\eta_{\text {father }}\right)}$. This lower bound in conjunction with our OLS and IV estimates of the intergenerational income elasticity allow us to estimate a lower bound of $\pi_{2}$ and an upper bound of $\pi_{1}$.

\section{Data}

\subsection{Data Sources and Description}

Our empirical analysis is based on data taken from a thirty-five percent sample of sons born in Sweden between 1950 and 1965 drawn from Statistic Sweden's multigenerational register 
(which covers all persons who were born in Sweden from 1932 onwards and have lived in Sweden at any time since 1961). Nearly all biological and adoptive parents of these sons are identified in this data set. The identification rate of fathers rises from 95 percent for those sons born in 1950 to 98 percent for those sons born in 1965. The multigenerational register also includes information on the year of birth and death (when applicable) of each individual. The register sample is then matched with data from the official Swedish tax register. We use data on income from all sources, or pre-tax total factor income, which is available from 1968 to 2005 to construct our main income measure for both fathers and sons. ${ }^{18}$

Our research design takes advantage of a number of potential correlates to fathers' income available to us beyond this straightforward measure of total market income including: education, occupation, and employment status. These variables are likely related to a range of possible effects on a father's human capital or on the idiosyncratic component of his income. The use of these variables as instruments will be discussed in more detail below.

Fathers' educational attainment is measured in 7 levels: (i) less than 9 years of primary, (ii) completed 9 years of primary, (iii) at most 2 years of secondary, (iv) 2 to 3 years of secondary, (v) less than 3 years of upper secondary, (vi) at least 3 years of upper secondary school, and (vii) graduate studies. Most of this information has been taken from Sweden's national education register for the year 1990. If a father's education was missing in this primary source, then secondary sources were searched. This was done in the following order: the national

\footnotetext{
18 The definition of this income measure changed in 1974 to include some social benefits, most notably unemployment compensation and illness benefits. Parental leave benefits were also included but were almost exclusively used by mothers. We have direct measures of these benefits for the 1974 to 1980 period, which we use to gauge the sensitivity of our estimates to their inclusion. We also include father birth-year dummies to control for this and other cohort-specific and/or time varying effects.
} 
education registers for 1993, 1996 and 1999 and, finally, the 1970 Census. ${ }^{19}$ Swedish Census data have also been used to identify a father's municipality of residence, ${ }^{20}$ his occupation and his employment status for the years 1960, 1965, 1970, 1975, 1980, 1985 and $1990 .^{21}$

\subsection{Measuring Permanent Income}

To estimate the intergenerational income elasticity (IIE) posited in model (1), we need measures of permanent income for fathers and sons. Our data, however, do not allow us to calculate actual permanent incomes for all fathers and sons. Instead, we are forced to use a proxy for permanent income.

Two main obstacles to constructing a high quality proxy for fathers' permanent income have been identified in the previous literature. The first is the presence of transitory income shocks in the data. This is likely to attenuate IIE estimates unless the proxy is constructed using a large number of years of fathers' income data (Solon 1992, Mazumder 2001, 2005). ${ }^{22}$ The second obstacle arises from the heterogeneity of life-cycle income profiles (Jenkins 1987, Haider and Solon 2006, Grawe 2006). In short, this literature tells us that fathers' incomes must be observed in the correct age range to capture accurate measures of differences in permanent incomes across individuals or groups. The problem of life-cycle bias also applies to our proxy of sons' permanent income, since it is a form of non-classical measurement error.

\footnotetext{
${ }^{19} 20$ percent of the data on fathers' education come from the 1970 census. Nearly all of the remaining information comes from the 1990 national education register. Information concerning education could not be found for 11 percent of the fathers in the full sample. But less than 0.5 percent is missing in our baseline sample.

${ }^{20}$ Between 1962 and 1974, Sweden reduced the number of municipalities from 1037 to 278. After 1974, this number was allowed to rise. Today Sweden is comprised of 290 municipalities.

${ }^{21}$ Although all censuses report some measure of employment, the employment status variables change from one census to the next. Employment status is coded from 0-9 in 1960, from 0-5 in 1965, 1-9 in 1970, 1975 and 1980 and 1-4 in 1985 and 1990. These differences are largely due to evolving approaches to measure part-time employment. Note also that there is no information on occupation in the 1965 census.

${ }^{22}$ In fact, this challenge is complicated even further by the existence of autocorrelation in transitory shocks to income and by the fact that the variance of these shocks may change over the life cycle.
} 
For our fathers, Böhlmark and Lindquist (2006) suggest that income measured after age 33 may act as a good proxy of permanent income. For our sons born in 1950, they tell us to look at a specific age, namely age 34. But since our sons are born between 1950 and 1965 and have (on average) more education than those studied by Böhlmark and Lindquist (2006), we choose to shift this age upwards by one year to age 35 .

Our proxy for permanent income of sons is calculated as follows. We use 11 years of income data for each son centered on age 35 , i.e., from age 30 to age $40 .{ }^{23}$ Nominal income is deflated using the Swedish consumer price index. We use the natural logarithm of an average of real income taken across these periods. A similar procedure is used to calculate the permanent income of fathers. The only difference is that fathers income is measured between age 30 and 60 . We argue that this proxy of fathers' permanent income is a high quality measure of permanent income that is largely free from both life-cycle bias and attenuation bias. ${ }^{24}$

Descriptive statistics for fathers' and sons' permanent income used in our baseline estimation can be seen in Table 1. To be included in the sample, we require at least 10 years of non-missing observations of income within the correct age window. Despite this somewhat loose demand on fathers' incomes, we still do not observe many missing values. The median number

\footnotetext{
${ }^{23}$ For sons born between 1950 and 1955 we can test to see if our proxy for sons' permanent income is free from lifecycle bias. We do this by re-calculating log average income for each son using income data from age 20 to 50 . This longer time series of income should provide us with a relatively good measure of permanent income for these cohorts (or, at the very least, an improved proxy for permanent income). We then regress our initial proxy onto this new measure of permanent income which produces an OLS regression coefficient equal to $1.01(0.002)$, where a coefficient of 1 indicates no life-cycle bias (see Haider and Solon 2006 or Böhlmark and Lindquist 2006). Unfortunately, we can not do this for our younger cohorts, because we simply don't have enough information concerning their incomes above age 40 . To run this experiment correctly we used all available sons, which gave us a sample size of 111,234 sons. If we re-do this experiment using only the 32 sons born between 1950 and 1955 who appear in our baseline sample, then the OLS coefficient is $0.98(0.104)$.

${ }^{24}$ Mazumder (2005) argues that averaging over 30 years of income largely eliminates attenuation bias unless transitory shocks demonstrate a very strong degree of autocorrelation. In this case, the reliability ratio may be as low as 0.9 even after averaging over 30 years of income. If we drop our demand of observing all fathers in the same age window (30 to 60), then we can average their incomes over 38 years as opposed to 31 years. The reliability ratio calculated as the $\mathrm{R}^{2}$ from a regression of our 31-year average onto this new 38-year average (called full-data income father in Table 2) is equal to 0.98. The OLS coefficient is equal to 0.99 (0.001).
} 
of missing values is zero and the mean is 0.71 . For sons, only 3 percent of the baseline sample has 1 out of 11 income observations missing.

The original probability sample of sons born between 1950 and 1965 contains information on 309,869 sons. Due to the demanding income requirements needed to run this intergenerational experiment properly, our sample shrinks to 24,114 father-son pairs. In Table 2, we compare our limited sample with the full sample along several dimensions. Income should differ between the two groups by construction; an individual is dropped from the sample when we do not have a sufficient number of income observations for that person. Despite this, the measures of income available to us differ only slightly between the two samples.

The average number of years of schooling obtained by our fathers is 0.33 years higher than fathers in the full sample. This is mainly due to the fact that the median birth year of our fathers is 1940 , while the median birth year of the fathers in the full sample is 1927. Most of our fathers faced an educational system with 9 years of compulsory schooling as opposed to the 7year system faced by those who were born before 1938. The median birth year of our sons is 1964. The median in the full sample is 1958 . Taken together, these differences produce an average age difference between fathers and sons of 31.37 in the full sample and only 22.79 in our sample. $^{25}$

\subsection{Our Instruments}

Our strategy for estimating the structural parameters in our model of intergenerational income mobility is based on the idea that different sources of paternal income have different implications

\footnotetext{
${ }^{25}$ This age difference is driven mainly by the fact that our selection rules have matched fathers to their first-born sons only. We have run an alternative experiment that used only 11 income years for fathers. The sample of sons used in this experiment rose to 132,210 . The average age difference was 26.49 years. The estimated IIE was only slightly lower than our baseline IIE.
} 
for filial income. In our model, income derived solely from luck identifies the direct effect that paternal income has on filial income, while income derived solely from fathers' human capital identifies the total effect that fathers' human capital has on their sons' incomes. In the absence of perfect instruments for luck and human capital, our strategy for bounding the structural parameters of the model entails investigating differences in a set of estimates of the IIE produced using an array of different instruments for fathers' permanent income. The only demands that we place on our instruments is that they satisfy the monotonicity condition stated earlier and that they be correlated with luck and human capital to varying degrees. In this manner, different estimates of the IIE will be identified using different sources of variation in fathers' permanent incomes that are more or less related to luck or to human capital.

Our instruments include fathers' level of education, years of schooling and occupation. We use his occupation in 1970, 1975, 1980, 1985 and 1990, which coincide with our income data. Our priors are that these instruments should be highly correlated with fathers' human capital. ${ }^{26}$ As instruments for luck, we wish to use instruments based on father's employment status in 1975, 1980, 1985 and 1990. However, employment status may also reflect a father's human capital levels and other systematic factors. To deal with this possibility we first regress employment status on the past education and earnings history of the father and use the residuals, purged of human capital influence, as our instruments. While imperfect, this plausibly captures loss of income due to bad "luck". ${ }^{27}$

\footnotetext{
${ }^{26}$ We also tried using the Swedish compulsory school reform as described in Meghir and Palme (2005) and Holmlund (2008) as an aggregate instrument for fathers' human capital. But it turned out to have no predictive power for fathers' permanent incomes. Similarly, instruments based on municipality of residence produced measures that were insufficiently precise to draw meaningful conclusions.

${ }^{27}$ We also experimented with instruments based on municipality of residence at early points in the father's work history or municipality interacted with birth cohort to try and capture random locale shocks that were due to "luck" (Freeman 1979; Welch 1979). While these also produce low point estimates they are insufficiently precise to warrant any substantive conclusions.
} 


\section{Results}

\subsection{Estimates}

Estimates of the father-son intergenerational income elasticity (IIE) are presented in Table 3. Our baseline IIE is shown in column 1 of Table 3 . The point estimate is 0.286 with a standard error of 0.011. Comparable estimates of the father-son IIE for Sweden can be found in Björklund and Chadwick (2003) and Björklund et al. (2008). Their estimates are 0.24 (0.01) and 0.251 (0.004), respectively. ${ }^{28}$ These previous researchers use the average of log income as compared to our measure which averages incomes across years before taking the natural logarithm. When we examine the average of log income, our IIE estimates falls to 0.245 (0.009), very similar to the prior literature. ${ }^{29}$

We now turn our attention to IV estimates of the IIE, which are also reported in Table 3. Recall that each estimate corresponds to a different combination of the impact of financial resources and the mechanistic transmission of human capital. We begin by examining the IIE when we instrument father's permanent income with years of education (column 2) and dummy variables for education category attained (column 3). The resulting point estimates are virtually identical at 0.417 and 0.414 , respectively. ${ }^{30}$ This estimate is significantly higher than our baseline OLS estimates, it suggests that we should reject a one-factor model of intergenerational

\footnotetext{
${ }^{28}$ Björklund and Chadwick's (2003) estimate is taken from their Table 4. It is the father-son elasticity for labor income. However, they state (on p. 241) that the basic pattern is the same when using total factor income (as we do). Björklund et al.'s (2008) estimate is taken from their Table 4b, which is the estimate that is most similar to our own in terms of restrictions on the data, etc. It is a father-son income elasticity similar to ours. The main differences are that they limit their sample to sons born between 1960 and 1967 and that they use fathers' income for those years their sons were actually living at home. Using an alternative data source together with an IV estimation strategy, Björklund and Jäntti (1997) estimated an intergenerational elasticity in father-son earnings of 0.28, which is the highest estimate that we have seen in the literature. Gustafsson (1994) and Österberg (2000) report estimates of the father-son earnings elasticity equal to 0.14 and 0.13 , respectively. These are the lowest estimates that we have seen and they can be readily explained by their use of limited information on earnings. Gustafsson only has access to 4 years of data for sons and 1 year of data for fathers, while Österberg (2000) only has access to 3 years of data for both fathers and sons.

${ }^{29}$ In Table 4d, Björklund et al. (2008) report an IIE for the log of average income equal to 0.287 (0.003).

${ }^{30}$ The standard errors are cluster corrected at the level of the father.
} 
income transmission. Furthermore, since these instruments plausibly isolate variation in paternal income associated with human capital, this IV estimate can also be used as an estimate of the parameters $\pi_{1}+\pi_{2}$ in our model.

The next regressions use instruments for paternal income based on measures of father's occupation. In column 4, we instrument using the cell mean of permanent income of fathers with the same occupation in 1970. This corresponds to the early part of the fathers' careers. We expect that initial choice of occupation is largely a reflection of human capital. Of course, to the extent that occupational wage differentials reflect job amenities or efficiency wages, occupational wages may also reflect variation in luck (in the context of our model), but we expect that to be a minor factor. Indeed, the resulting the IV estimate is 0.40 , very similar to the results observed with the paternal education instruments. Once again, the human capital instrument produces a significantly different estimate than OLS.

In column 5 we expand our time frame and construct instruments using the cell mean of a father's permanent income for each observed occupation in 1970, 1975, 1980, 1985, and 1990. This takes into account occupational transitions that may be associated with either human capital or luck. The resulting estimate is 0.34 , lower than the estimate associated with initial occupation but still higher than the OLS estimates.

Our next set of IV specifications relies on the employment status of fathers, which we observe every five years. We begin our examination in 1970 as prior to this many fathers in the sample have not yet finished their schooling. In column 6 we instrument father's permanent income with employment status dummies from all of the periods (1970-1990) simultaneously. This produces an estimate of 0.20 , significantly lower than the OLS baseline. 
During the working lives of fathers in our sample, Sweden had very low unemployment. As a consequence, those fathers who we observe unemployed may have had particularly low human capital or attachment to the labor force. To construct an instrument which more effectively isolates the employment variation attributable to luck, we orthogonalize fathers' employment status in a particular period against years of schooling and earnings up to the reference date. In column 7, we repeat our analysis using the residual measure of employment status in each time period after 1970. As expected, once purged of human capital effects, our estimates are even lower, albeit less precise with a point estimate of 0.11 with a standard error of .07 .

\subsection{Decomposing the IIE}

In our model, the observed OLS IIE is a function of three parameters: the causal impact of financial resources on child outcomes $\left(\pi_{1}\right)$, the mechanistic transmission of human capital $\left(\pi_{2}\right)$, and the fraction of variance of paternal permanent income explained by human capital $\left(R^{2}\right)$. Given that our years of schooling variable induces variation in father's permanent income only on account of human capital, we have a consistent estimate of $\pi_{1}+\pi_{2}$. To fully identify all parameters of the model, we need additional information regarding either $\pi_{1}$ or $R^{2}$.

In order to capture a true estimate of $\pi_{1}$, we would need an instrument that induces variation in parental income solely due to luck. Obviously, a perfect instrument that captures only luck yet is sufficiently prevalent to induce enough variation to provide precise estimates is difficult to find. Indeed, if it were readily available, instrumental variables estimates settling the question of how much money matters would be ubiquitous. Fortunately, our model suggests that an imperfect luck instrument may still allow us to make progress in the decomposition by 
providing an upper bound for $\pi_{1}$. While we might argue that the residuals based on employment status are good luck instruments, it is more important that they provide an upper bound. Thus, for the purposes of this specification, our estimate of $\pi_{1}$ is identified by the IV estimate of the impact of paternal income using the employment residual instruments, $\hat{\beta}_{1}^{I V E m p R e s i d}$. Further, $\pi_{1}+\pi_{2}$ is identified by the IV estimate that uses dummy variables for educational attainment as instruments, $\hat{\beta}_{1}^{\text {IV EdCat }}$. These in conjunction with the OLS estimate of the IIE, $\hat{\beta}_{1}^{\text {oLS }}$, allow us to estimate $\pi_{2}=\hat{\beta}_{1}^{I V E d C a t}-\hat{\beta}_{1}^{I V E m p R e s i d}$ and the fraction of variance in permanent income attributable to human capital, $R^{2}=\left(\hat{\beta}_{1}^{\text {oLS }}-\hat{\beta}_{1}^{\text {IV EmpResid }}\right) /\left(\hat{\beta}_{1}^{I V E d C a t}-\hat{\beta}_{1}^{\text {IV EmpResid }}\right)$. These results are reported in the first specification of Table 4. We note that the implied causal effect of father's permanent income on the next generation's incomes is bounded from above by 0.11 , making 0.31 a lower bound of the mechanistic impact of human capital on filial income. These estimates further imply that 58 percent of the variation in paternal income is attributable to human capital. This bounding exercise would suggest that 37 percent of the IIE reflects the causal effect of financial resources while the balance captures the mechanistic impact of human capital.

As an alternative, we can identify the model using a credible estimate of the fraction of the father's income variation due to human capital, in other words the $\mathrm{R}^{2}$ from a correctly specified Mincer regression. Of course, we are unlikely to observe all aspects of paternal human capital, so the observed Mincer r-squared is likely to represent a lower bound to the truth. We first calculate this r-squared using our analysis data set. We regress paternal human capital on dummy variables for educational attainment and 1990 occupation. $^{31}$ The adjusted r-squared

\footnotetext{
${ }^{31}$ Occupation may reflect a realized favorable employment outcome in addition to human capital. This raises the possibility that the r-squared need not be a lower bound of the impact of human capital. The fact that occupation
} 
from this regression is 0.376 . Using $\hat{\beta}_{1}^{I V E d C a t}$ as our estimate of $\pi_{1}+\pi_{2}$, we calculate $\pi_{1}=\left(\hat{\beta}_{1}^{\text {oLS }}-\hat{R}^{2} \hat{\beta}_{1}^{I V E d C a t}\right) /\left(1-\hat{R}^{2}\right)$ and $\pi_{2}=\pi_{1}-\left(\hat{\beta}_{1}^{\text {OLS }}-\hat{R}^{2} \hat{\beta}_{1}^{I V E d C a t}\right) /\left(1-\hat{R}^{2}\right)$. The estimates are shown in the second specification of Table 4. In this case, our upper bound estimate of $\pi_{1}$ is 0.21 and our lower bound estimate of $\pi_{2}$ is 0.20 . In this case, the causal effect of financial resources accounts for nearly three-quarters of the intergenerational income elasticity. The benefit of additional human capital on son's earnings operates nearly equally through mechanistic and financial channels.

Of course, each r-squared implies a different set of structural parameters. Figure 1 shows the implied causal effect of financial resources associated with each possible r-squared measure. We see that if the true r-squared value is low, the majority of the correlation between father's and son's income operates through a causal money effect. These are computed in manner identical to the prior two paragraphs. As the r-squared rises, the implied effect of financial resources falls. For a Mincerian r-squared of about .7, the implied causal effect of financial resources is zero.

\subsection{Robustness Checks}

There are a number of potential concerns regarding the validity and interpretation of our estimates. One concern is that our measure of permanent income is the log of the average of yearly incomes. Many prior researchers average log yearly income. This places greater weight on periods of low income relative to our analysis. In Table 5, we show our estimates and decomposition using this alternative measure of fathers' and sons' income. When we use the

dummies yield similar IV estimates of the impact of paternal human capital as education dummies suggest they reflect primarily human capital. 
average of log income, the results are qualitatively similar though the causal effect of fathers' income, $\pi_{1}$, is a somewhat larger component of the IIE.

A second concern is that the identification of the independent effects of human capital and financial resources depends on the linearity of our model. If, for example, the relationship between financial resources and son's income was non-linear, OLS and IV estimates could differ because of the different weights they might place on high versus low income fathers. ${ }^{32}$ The same is true for IV estimates generated from multiple instruments. To test the importance of this possibility we examine the weighting function for our instrumental variables regressions that use education as an instrument. To do this we divide education into binary classes of high versus low education and calculate the difference in cumulative distribution functions of income across the two education classes. This difference in cdf's shows how IV weights the various parts of the fathers' income distribution when estimating the impact of additional funding. ${ }^{33}$ To see if our analysis is sensitive to this weighting, we perform a weighted least squares regression using a weighting function designed to mimic the IV weights across the distribution of paternal income. The resulting coefficient is found in the second row of Table 6 and is less than a standard error away from our baseline OLS estimate of the IIE. We conclude that the difference in coefficients is not due to non-linearities in the father-son income relationship coupled with differential estimator weighting.

In addition to concerns that the impact of paternal income on child quality may be nonlinear, we may also be concerned that paternal human capital and income may not be separable. This would be true if high human capital fathers value child quality more highly and thus spend a higher fraction of their income on human capital investments. It would also be the case if the

\footnotetext{
${ }^{32}$ Bratsberg et al. (2007), Corak and Heisz (1998), and Grawe (2004) present conflicting evidence regarding the existence of non-linearities in the relationship between father's and son's income.

${ }^{33}$ See Angrist and Imbens (1995).
} 
financial investments of high human capital fathers were more productive than those of low productivity fathers. In either of these cases $\pi_{1}$ varies across households on the basis of paternal human capital. We examine this concern using two approaches. First, we regress son's income on father's income separately by education category. We realize that education is only a crude proxy for human capital but it is still insightful to see if the relationship between paternal and filial income is substantially different across these categories. These results are shown in Table 6. Due to the procedure conditioning on education, the average IIE within education category will be somewhat lower than our baseline OLS estimate. The estimates across education categories are qualitatively similar with the exception of fathers who completed graduate school. For this group, the IIE is much larger though quite imprecise. Given that it is estimated from a sample of only 163 fathers, it should probably be discounted. Testing to see whether the estimates are jointly identical, we obtain a p-value of 0.055 .

Another test that allows us to examine the separability of human capital and income is to see whether exploiting variation in different parts of the education distribution yields different IV estimates of the IIE. For example, if the impact of financial resources was different for low human capital fathers than for high human capital fathers, the IV estimate we obtain by comparing very low education fathers with the rest of the sample should be different from the IV estimate obtained comparing very high education fathers to the rest of the sample. In Table 6, we show IV estimates in which the instrument is a dummy variable which takes on a value of 1 if the father is in the relevant education group and zero otherwise. Examining the results, the IV estimates are quite similar regardless of which education dummy variable we use as an instrument. The sole exception is when we instrument permanent income with a dummy variable that takes on a value of one if the father has exactly nine years of education. This point 
estimate is very imprecise, however. One cannot reject that these instruments collectively yield the same point estimate.

Our model only includes two transmission mechanisms through which paternal income affects filial income: financial investments and human capital. However, human capital is an aggregate of genetics, education, social skills, and other factors. The aggregation of these components into a single factor is appropriate as long as each component, when denominated in income equivalents, has the same rate of transmission to filial income. More specifically, an increase in paternal IQ that generates $\$ 1000$ of paternal income needs to have the same effect on son's income as an increase in paternal education that generates the same rise in paternal income. This assumption is testable given two instruments that are plausibly uncorrelated to luck that capture different dimensions of human capital. If our aggregation to a single human capital factor is warranted, the resulting IV estimates should be close. In Table 4, the education instruments of columns (1)-(2) produce similar results to the father's initial occupation instruments of column (3). Although it is possible that their similarity is due to an overlap in the dimensions of human capital they measure it is nevertheless encouraging to see little divergence.

\section{Conclusion}

There is a substantial agreement in economics that characteristics such as income, IQ and education level are correlated across generations. What is less clear is the relative importance of different intergenerational transmission mechanisms. In particular there is no consensus on the expected effects of adding a dollar to a father's income on his sons' incomes holding other factors constant. In this paper we suggest a way to begin untangling the possible mechanisms through which the observed IIE operates. We start with a simple two factor model and show its 
implications for isolating the effect of monetary resources. Coupled with a rich longitudinal data set this allows us to estimate the separate contributions of money and human capital to observed correlations in intergenerational income.

We reject the one-factor model of intergenerational income correlation and estimate that no more than 37 percent of the correlation between father's and son's income operates through the causal effect of financial resources. Furthermore, the impact of paternal human capital on son's earnings operates primarily mechanistically as opposed to financial channels.

Our simple structural framework also shows how the OLS IIE, the estimated impact of paternal human capital on son's earnings, and the r-squared from a Mincer regression jointly identify the causal effect of financial resources. While in our context, this produced less informative bounds than our alternative strategy, we were able to able to map out the implied causal effect of paternal income associated with each measure of r-squared. This provides another potentially fruitful research angle to gain future insights regarding the importance of financial resources.

Going forward, it will be helpful to further test the assumptions underlying our model. Examining how the structural parameters underlying the IIE vary across countries would shed light on the roles of money and human capital across institutional settings. A straightforward extension to a three factor model might allow the IIE to be affected by income, genetic parental endowments, and non-genetically mediated human capital factors.

\section{References}

Aakvik, Arild, Kjell G. Salvanes, and Kjell Vaage. (2005). Educational Attainment and Family Background. German Economic Review (6), 377-394. 
Angrist, Joshua D. and Guido W. Imbens. (1995). Two-Stage Least Squares Estimation of Average Causal Effects in Models with Variable Treatment Intensity. Journal of the American Statistical Association (90), 431-442.

Becker, Gary S., and Nigel Tomes. (1979). An Equilibrium Theory of the Distribution of Income and Intergenerational Mobility. Journal of Political Economy (87), 1153-89.

Becker, Gary S., and Nigel Tomes. (1986). Human Capital and the Rise and Fall of Families. Journal of Labor Economics (4), 1-39.

Behrman, Jere Richard, and Mark R. Rosenzweig. (2002). Does Increasing Women's Schooling Raise the Schooling of the Next Generation? American Economic Review (92), 323-34.

Björklund, Anders, Karin Hederos Eriksson, and Markus Jäntti. (2009). IQ and Family Background: Are Associations Strong or Weak? IZA Discussion Paper No. 4305.

Björklund, Anders, and Markus Jäntti. (2009). Intergenerational income mobility and the role of family background. InWiemer Salverda, Brian Nolan, and Timothy M Smeeding, editors, Oxford Handbook of Economic Inequality, chapter 20. Oxford University Press, Oxford.

Bjorklund, Anders, and Markus Jantii. (1997). Intergenerational Mobility in Sweden Compared to the United States. American Economic Review (87), 377-386.

Björklund, Anders, Markus Jäntti and Gary Solon. (2005). Influence of Nature and Nurture on Earnings Variation: A Report on a Study of Various Sibling Types in Sweden. In Samuel Bowles, Herbert Gintis and Melissa Osborne Groves, editors, Unequal Chances: Family Background and Economic Success. Russel Sage Foundation, Princeton University Press, Princeton.

Björklund, Anders, Markus Jäntti and Gary Solon. (2007). Nature and Nurture in the Intergenerational Transmission of Socioeconomic Status: Evidence from Swedish 
Children and Their Biological and Rearing Parents. The Berkley Electronic Journal of Economic Analysis \& Policy: Vol. 7: Iss. 2 (Advances), Article 4.

Björklund, Anders, Mikael Lindahl and Erik Plug. (2006). The Origins of Intergenerational Associations: Lessons from Swedish Adoption Data. The Quarterly Journal of Economics 121(3), 999-1028.

Björklund, Anders, and Laura Chadwick. (2003). Intergenerational Income Mobility in Permanent and Separated Families. Economics Letters (80), 239-46.

Black, Sandra E., Paul J. Devereux, and Kjell G. Salvanes. (2008). Like Father, Like Son? A Note on the Intergenerational Transmission of IQ Scores. NBER Working Paper 14274.

Black, Sandra E., Paul J. Devereux and Kjell G. Salvanes. (2005). The More The Merrier? The Effect of Family Size and Birth Order on Children's Education. Quarterly Journal of Economics (120), 669-700.

Blanden, Jo, Paul Gregg and Lindsey Macmillan. (2007). Accounting for Intergenerational Income Persistence: Noncognitive Skills, Ability and Education. Economic Journal 117(519), C43-C60.

Blau, David. (1999). The Effect of Income on Child Development. The Review of Economics and Statistics (81), 261-76.

Böhlmark, Anders, and Matthew J. Lindquist. (2006). Life-Cycle Variations in the Association between Current and Lifetime Income: Replication and Extension for Sweden. Journal of Labor Economics 24(4), 879-900.

Bouchard, Thomas J. Jr., and Matthew McGue. (1981). Familial Studies of Intelligence: A Review. Science (212), 1055-59. 
Bratsberg, Bernt, Knut Røed, Oddbjørn Raaum, Robin Naylor, Markus Jantti, Tor Eriksson, and Eva Osterbacka. (2007). Nonlinearities in Intergenerational Earnings Mobility: Consequences for Cross-Country Comparisons. Economic Journal 117(519), C72-C92

Carneiro, Pedro, and James J. Heckman. (2002). The Evidence on Credit Constraints in PostSecondary Schooling. Economic Journal (112), 705-34.

Checchi, Daniele, Andrea Ichino, and Aldo Rustichini. (1999). More Equal but Less Mobile?: Education Financing and Intergenerational Mobility in Italy and in the US. Journal of Public Economics (74), 351-93.

Corak, Miles, and Andrew Heisz. (1998). The Intergenerational Earnings and Income Mobility of Canadian Men: Evidence from Longitudinal Income Tax Data. Analytical Studies Branch Research Paper Series 1998113e, Statistics Canada, Analytical Studies Branch. Corcoran, Terry, Jerry Sexton, and Declan O'Donoghue. (1992). A Review of Trends in the Occupational Pattern of Employment in Ireland 1971-1990. No BMI68 in Forecasting Report from Economic and Social Research Institute.

Dahl, Gordon, and Lance Lochner. (2008). The Impact of Family Income on Child Achievement: Evidence from the Earned Income Tax Credit. NBER Working Paper 14599.

Davies, James Byron, Jie Zhang, and Jinli Zeng. (2005). Intergenerational Mobility under Private vs. Public Education. Scandinavian Journal of Economics (107), 399-417. Goldberger, Arthur S. (1989). Economics and Mechanical Models of Intergenerational Transmission. American Economic Review (79), 504-13.

Grawe, Nathan D. (2006). Lifecycle Bias in Estimates of Intergenerational Earnings Persistance. Labour Economics (13), 551-70. 
Grawe, Nathan D. (2004). Reconsidering the Use of Nonlinearities in Intergenerational Earnings Mobility as a Test for Credit Constraints. Journal of Human Resources (39), 813-27.

Gustafsson, Bjorn. (1994). The degree and pattern of income immobility in Sweden. Review of Income and Wealth (40), 67-86.

Haider, Steven J., and Gary Solon. (2006). Life-Cycle Variation in the Association between Current and Lifetime Earnings. American Economic Review (96), 1308-20.

Hassler, John, Sevi Rodríguez Mora, and Joseph Zeira. (2007). Inequality and Mobility. Journal of Economic Growth (12), 235-59.

Hauser, Robert M., and John A. Logan. (1992). How Not to Measure Occupational Inheritance (An invited critique on Rytima's proposal). American Journal of Sociology (97), 16891711.

Holmlund, Helena. (2008). A researcher's guide to the Swedish compulsory school reform. CEEDP working Paper 87. Centre for the Economics of Education, London School of Economics and Political Science, London, UK.

Holmlund, Helena, Mikael Lindahl and Erik Plug. (2008). The Causal Effect of Parent's Schooling on Children's Schooling: A Comparison of Estimation Methods. IZA Discussion Paper No. 3630.

Hussain, Mohammad Azhar, Martin D. Munk, and Jens Bonke. (2008). How Sensitive is Intergenerational Earnings Mobility to Different Measures? Working Paper 07:2998. Danish National Center for Social Research. Copenhagen.

Imbens, Guido, and Joshua Angrist. (1994). Identification and Estimation of Local Average Treatment Effects. Econometrica (62), 467-75. 
Jacob, Brian A., Lars Lefgren, and David Sims. (Forthcoming). The Persistence of TeacherInduced Learning. Journal of Human Resources.

Jenkins, Stephen. (1987). The Implications of "Stochastic" Demographic Assumptions for Models of the Distribution of Inherited Wealth: Correction. Bulletin of Economic Research (39), 185.

Lefranc, Arnaud, and Alain Trannoy. (2005). Intergenerational Earnings Mobility in France: Is France More Mobile than the U.S.? Annales d'Economie et de Statistique (78), 57-77. Liu, Haoming and Jinli Zeng. (2009). Genetic Ability and Intergenerational Earnings Mobility. Journal of Population Economics 22(1), 75-95.

Mayer, Susan E. (1997). What Money Can't Buy: Family Income and Children's Life Chances, Harvard University Press, Cambridge, MA.

Mazumder, Bhashkar. (2005). Fortunate Sons: New Estimates of Intergenerational Mobility in the United States Using Social Security Earnings Data. The Review of Economics and Statistics (87), 235-55.

Mazumder, Bhashkar. (2001). Earnings Mobility in the US: A New Look at Intergenerational Inequality. Federal Reserve Bank of Chicago Working Paper WP-01-18.

Meghir, Costas, and Mårten Palme. (2005). Educational Reform, Ability, and Family Background. American Economic Review 95(1), 414-424.

Mulligan, Casey B. (1999). Galton versus the Human Capital Approach to Inheritance. Journal of Political Economy (107), 184-224.

Oreopoulos, Philip, Marianne E. Page, and Ann Huff Stevens. (2006). The Intergenerational Effects of Compulsory Schooling. Journal of Labor Economics (24), 729-60. 
Österberg, Torun. (2000). Intergenerational Income Mobility in Sweden: What do Tax-Data Show? Review of Income and Wealth (46), 421-436.

Pekkarinen, Tuomas, Roope Uusitalo, and Sari Pekkala Kerr. (2009). School Tracking and Intergenerational Income Mobility: Evidence from the Finnish Comprehensive School Reform. Journal of Public Economics 93(7-8), 965-973.

Piraino, Patrizio. (2007). Comparable Estimates of Intergenerational Income Mobility in Italy. The B.E. Journal of Economic Analysis \& Policy (7), 1711-37.

Shea, John. (2000). Does Parents' Money Matter? Journal of Public Economics (77), 155-84.

Solon, Gary. (1992). Intergenerational Income Mobility in the United States. American Economic Review (82), 393-408.

Solon, Gary. (1999). Intergenerational Mobility in the Labor Market. Chapter 29 in Handbook of Labor Economics (3), 1761-1800.

Solon, Gary. (2004). A Model of Intergenerational Mobility Variation over Time and Place. In Miles Corak, editor, Generational Income Mobility in North America and Europe, chapter 2. Cambridge University Press, Cambridge.

Zimmerman, David J. (1992). Regression Toward Mediocrity in Economic Stature. American Economic Review (82), 409-29. 


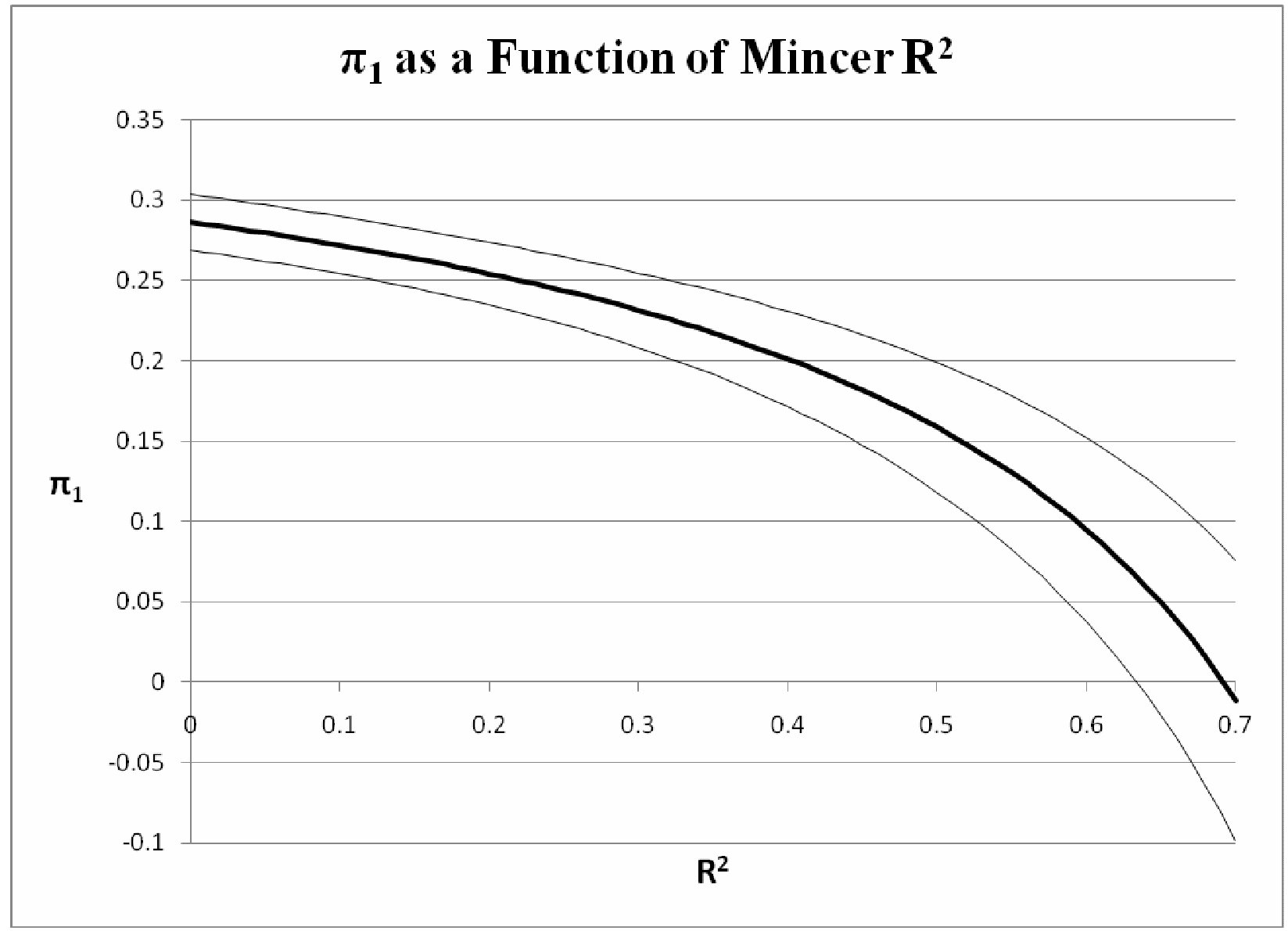

Figure 1: The relationship between the causal effect of parental money on filial income $\left(\pi_{1}\right)$ as a function of the fraction of fathers' incomes explained by human capital (Mincer $\mathrm{R}^{2}$ ) 
Table 1. Descriptive Statistics for Fathers and Sons Used in Our Baseline Estimation.

\begin{tabular}{|c|c|c|c|c|c|c|c|c|}
\hline Average & \multicolumn{4}{|c|}{ Missing income observations } & \multicolumn{3}{|c|}{ Birth year } & \\
\hline $\begin{array}{l}\text { income }^{\mathrm{a}} \\
\text { (s.d.) }\end{array}$ & Min & Median & Mean & $\operatorname{Max}$ & Min & Median & Max & observations \\
\hline
\end{tabular}

\section{Fathers}

\begin{tabular}{|c|c|c|c|c|c|c|c|c|c|}
\hline All & $\begin{array}{c}12.31 \\
(0.392)\end{array}$ & 0 & 0 & 0.71 & 21 & 1938 & 1940 & 1945 & 24114 \\
\hline & \multicolumn{9}{|c|}{ Fathers tabulated according to the number of sons they contribute to the sample } \\
\hline 1 & $\begin{array}{c}12.32 \\
(0.392)\end{array}$ & 0 & 0 & 0.71 & 21 & 1938 & 1940 & 1945 & 22960 \\
\hline 2 & $\begin{array}{c}12.26 \\
(0.374)\end{array}$ & 0 & 0 & 0.79 & 18 & 1938 & 1939 & 1945 & 1122 \\
\hline 3 & $\begin{array}{c}12.11 \\
(0.345)\end{array}$ & 0 & 0 & 1.39 & 11 & 1938 & 1939 & 1942 & 31 \\
\hline 4 & $\begin{array}{l}11.78 \\
\text { (n.a.) }\end{array}$ & 5 & 5 & 5 & 5 & 1938 & 1938 & 1938 & 1 \\
\hline
\end{tabular}

\section{Sons}

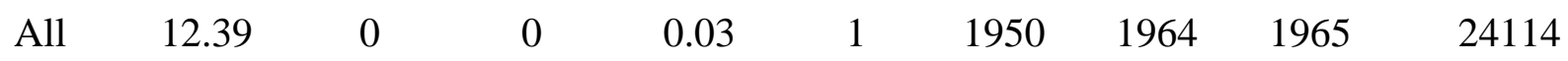
$(0.431)$

a) Calculated using fathers' incomes between the ages of 30 and 60 and using sons' incomes between the ages of 30 and 40. Zero incomes and missing are both treated as missing. We require at least 10 years of non-missing incomes to be included in the sample. 
Table 2. Descriptive Statistics for the Full Sample and for Our Sample.

\begin{tabular}{|c|c|c|c|c|c|c|c|c|}
\hline & $\begin{array}{c}\text { Full- } \\
\text { data } \\
\text { income }^{a} \\
\text { son }\end{array}$ & $\begin{array}{c}\text { 11-year } \\
\text { average } \\
\text { son's } \\
\text { income }^{b}\end{array}$ & $\begin{array}{c}\text { Full- } \\
\text { data } \\
\text { income }^{\mathrm{a}} \\
\text { father }\end{array}$ & $\begin{array}{l}\text { 11-year } \\
\text { average } \\
\text { father's } \\
\text { income }^{\text {b }}\end{array}$ & $\begin{array}{l}\text { Years of } \\
\text { schooling } \\
\text { father }\end{array}$ & $\begin{array}{c}\text { Median } \\
\text { birth } \\
\text { year } \\
\text { son } \\
\end{array}$ & $\begin{array}{c}\text { Median } \\
\text { birth } \\
\text { year } \\
\text { father }\end{array}$ & $\begin{array}{c}\text { Mean } \\
\text { father-son } \\
\text { age } \\
\text { difference }\end{array}$ \\
\hline \multicolumn{9}{|c|}{ Full sample } \\
\hline \multirow{3}{*}{$\begin{array}{l}\text { Mean } \\
\text { (s.d.) } \\
\text { Number } \\
\text { of obs. }\end{array}$} & $\begin{array}{c}12.09 \\
(0.495)\end{array}$ & $\begin{array}{c}12.26 \\
(0.591)\end{array}$ & $\begin{array}{c}12.19 \\
(0.518)\end{array}$ & $\begin{array}{c}12.24 \\
(0.521)\end{array}$ & $\begin{array}{c}9.51 \\
(2.983)\end{array}$ & 1958 & 1927 & $\begin{array}{c}31.37 \\
(7.038)\end{array}$ \\
\hline & 303886 & 298160 & 294862 & 136359 & 276158 & 309869 & 303141 & 303141 \\
\hline & \multicolumn{8}{|c|}{ Our sample } \\
\hline $\begin{array}{l}\text { Mean } \\
\text { (s.d.) }\end{array}$ & $\begin{array}{c}12.07 \\
(0.338)\end{array}$ & $\begin{array}{c}12.39 \\
(0.431)\end{array}$ & $\begin{array}{c}12.32 \\
(0.391)\end{array}$ & $\begin{array}{c}12.24 \\
(0.394)\end{array}$ & $\begin{array}{c}9.84 \\
(2.807)\end{array}$ & 1964 & 1940 & $\begin{array}{c}22.79 \\
(2.313)\end{array}$ \\
\hline $\begin{array}{l}\text { Number } \\
\text { of obs. }\end{array}$ & 24114 & 24114 & 24114 & 24114 & 24114 & 24114 & 24114 & 24114 \\
\hline
\end{tabular}


Table 3. Instrumental Variables estimates of the Father-Son Income

\begin{tabular}{|c|c|c|c|c|c|c|c|}
\hline & & \multicolumn{6}{|c|}{ Instrument } \\
\hline & $\begin{array}{l}\text { Ordinary } \\
\text { Least } \\
\text { Squares } \\
(1) \\
\end{array}$ & $\begin{array}{l}\text { Father Years } \\
\text { of Schooling } \\
\text { (2) }\end{array}$ & $\begin{array}{l}\text { Father Level } \\
\text { of Education } \\
\text { (3) }\end{array}$ & $\begin{array}{c}\text { Father } \\
\text { Occupation } \\
(1970) \\
(4) \\
\end{array}$ & $\begin{array}{c}\text { Father } \\
\text { Occupation } \\
(1970-1990) \\
(5)\end{array}$ & $\begin{array}{c}\text { Father } \\
\text { Employment } \\
\text { Status } \\
(6) \\
\end{array}$ & $\begin{array}{c}\text { Father } \\
\text { Employment } \\
\text { Residuals } \\
\text { (7) }\end{array}$ \\
\hline $\begin{array}{l}\text { Fathers' permanent } \\
\text { income }\end{array}$ & $\begin{array}{l}0.286^{*} \\
(0.019)\end{array}$ & $\begin{array}{l}0.417 * \\
(0.017)\end{array}$ & $\begin{array}{l}0.414^{*} \\
(0.018)\end{array}$ & $\begin{array}{l}0.400 * \\
(0.015)\end{array}$ & $\begin{array}{l}0.335^{*} \\
(0.012)\end{array}$ & $\begin{array}{l}0.205^{*} \\
(0.015)\end{array}$ & $\begin{array}{c}0.106 \\
(0.061)\end{array}$ \\
\hline $\begin{array}{l}\text { P-value of test that } \\
\text { IV=OLS }\end{array}$ & & 0.000 & 0.000 & 0.000 & 0.000 & 0.000 & 0.003 \\
\hline $\begin{array}{l}\text { First Stage F-statistic } \\
\text { [p-value] }\end{array}$ & & $\begin{array}{c}2630 \\
{[0.00]}\end{array}$ & $\begin{array}{c}564 \\
{[0.00]}\end{array}$ & $\begin{array}{c}6254 \\
{[0.00]}\end{array}$ & $\begin{array}{c}2756 \\
{[0.00]}\end{array}$ & $\begin{array}{c}858 \\
{[0.00]}\end{array}$ & $\begin{array}{c}39 \\
{[0.00]}\end{array}$ \\
\hline Observations & 24,114 & 24,114 & 24,114 & 24,114 & 24,114 & 24,114 & 24,114 \\
\hline
\end{tabular}


Table 4. Identification of Structural Parameters (Log of Average Income)

\begin{tabular}{|c|c|c|c|c|c|c|}
\hline & & \multicolumn{5}{|c|}{ Parameter } \\
\hline & & OLS IIE & $\pi_{1}$ & $\pi_{1}+\pi_{2}$ & $\pi_{2}$ & Mincer $R^{2}$ \\
\hline \multirow{2}{*}{ (1) } & $\begin{array}{l}\text { Parameter } \\
\text { Estimate }\end{array}$ & $\begin{array}{l}0.286 * \\
(0.010)\end{array}$ & $\begin{array}{c}0.106 \\
(0.061)\end{array}$ & $\begin{array}{l}0.417 * \\
(0.017)\end{array}$ & $\begin{array}{l}0.307 * \\
(0.064)\end{array}$ & $\begin{array}{l}0.579 * \\
(0.125)\end{array}$ \\
\hline & $\begin{array}{l}\text { Identification } \\
\text { Method }\end{array}$ & OLS & $\begin{array}{l}\text { Employment } \\
\text { Residuals IV }\end{array}$ & $\begin{array}{c}\text { Education Category } \\
\text { IV }\end{array}$ & Implied by Model & Implied by Model \\
\hline \multirow{2}{*}{ (2) } & $\begin{array}{l}\text { Parameter } \\
\text { Estimate }\end{array}$ & $\begin{array}{l}0.286 * \\
(0.010)\end{array}$ & $\begin{array}{l}0.209 * \\
(0.016)\end{array}$ & $\begin{array}{l}0.417 * \\
(0.017)\end{array}$ & $\begin{array}{l}0.205 * \\
(0.027)\end{array}$ & $\begin{array}{l}0.376 * \\
(0.007)\end{array}$ \\
\hline & $\begin{array}{l}\text { Identification } \\
\text { Method }\end{array}$ & OLS & Implied by Model & $\begin{array}{c}\text { Education Category } \\
\text { IV }\end{array}$ & Implied by Model & $\begin{array}{l}\text { Estimated from } \\
\text { Primary Sample }\end{array}$ \\
\hline
\end{tabular}


Table 5. Identification of Structural Parameters (Average of Log Income)

\begin{tabular}{|c|c|c|c|c|c|c|}
\hline & & \multicolumn{5}{|c|}{ Parameter } \\
\hline & & OLS IIE & $\pi_{1}$ & $\pi_{1}+\pi_{2}$ & $\pi_{2}$ & Mincer $R^{2}$ \\
\hline \multirow{2}{*}{ (1) } & $\begin{array}{l}\text { Parameter } \\
\text { Estimate }\end{array}$ & $\begin{array}{l}0.248 * \\
(0.010)\end{array}$ & $\begin{array}{l}0.135 * \\
(0.045)\end{array}$ & $\begin{array}{l}0.348 * \\
(0.024)\end{array}$ & $\begin{array}{l}0.213 * \\
(0.066)\end{array}$ & $\begin{array}{l}0.532 * \\
(0.179)\end{array}$ \\
\hline & $\begin{array}{l}\text { Identification } \\
\text { Method }\end{array}$ & OLS & $\begin{array}{l}\text { Employment } \\
\text { Residuals IV }\end{array}$ & $\begin{array}{c}\text { Education Category } \\
\text { IV }\end{array}$ & Implied by Model & Implied by Model \\
\hline \multirow{2}{*}{ (2) } & $\begin{array}{l}\text { Parameter } \\
\text { Estimate }\end{array}$ & $\begin{array}{l}0.248 * \\
(0.010)\end{array}$ & $\begin{array}{l}0.196 * \\
(0.015)\end{array}$ & $\begin{array}{l}0.348 * \\
(0.024)\end{array}$ & $\begin{array}{l}0.151 * \\
(0.033)\end{array}$ & $\begin{array}{l}0.341 * \\
(0.006)\end{array}$ \\
\hline & $\begin{array}{l}\text { Identification } \\
\text { Method }\end{array}$ & OLS & Implied by Model & $\begin{array}{c}\text { Education Category } \\
\text { IV }\end{array}$ & Implied by Model & $\begin{array}{l}\text { Estimated from } \\
\text { Primary Sample }\end{array}$ \\
\hline
\end{tabular}


Weighted Least Squares Using IV Weighting Function

OLS Estimates by Education Category

Less than 9 years

$0.232 *$

(0.014)

$0.233^{*}$

9 years

(0.031)

$0.257 *$

2 years secondary education

(0.019)

2-3 years secondary education

$0.301 *$

(0.024)

$0.279 *$

Less than 3 years upper secondary education

(0.035)

$0.285^{*}$

3 years upper secondary education

(0.038)

$0.758^{*}$

Graduate study

(0.260)

IV Estimates by Instrument(s)

all education categories

$0.417 *$

(0.024)

$0.443^{*}$

less than 9 years

(0.029)

9 years

$-0.274$

(0.368)

$0.444^{*}$

2 years secondary education

(0.075)

$0.442 *$

2-3 years secondary education

(0.046)

$0.453^{*}$

Less than 3 years upper secondary education

(0.055)

$0.388^{*}$

3 years upper secondary education

(0.037)

$0.374 *$

Graduate study 